\title{
CUNEUS EQUITUM ARCADUM AND CLASSIS [IN]PLATEYPEGIIS AT HALMYRIS. AN EXCHANGE OF TROOPS BETWEEN EGYPT AND THRACE DURING THE REIGN OF THEODOSIUS I. THE CASE OF SCYTHIA
}

Mihail Zahariade

\section{Cuneus equitum arcadum şi classis [in]plateypegiis la Halmyris. Un schimb de trupe între Egypt şi Thracia în timpul domniei lui Theodosius I. Cazul din Scytia}

Cuneus equitum Arcadum şi classis [in] Plateypegiis par foarte probabil să fi reprezentat o parte din efectivele aduse din Egipt pentru întărirea capacității defensive a provinciei Scythia, conform programului theodosian descris de Zosimos. Termenul de classis Inplateypegiis din sectiunea Scythica a Notitiei Dignitatum implica o flotilă de plateypegia aptă de a naviga în apele puțin adânci ale Deltei Dunării si a dat naştere unui toponim ce denumea baza acestei flotile, aflată fie într-unul din ostroavele Deltei, fie chiar la gurile brațului Sfântu Gheorghe în forma pe care o avea la acea dată.

Key words: Scytia, Egypt, Thrace, Cuneus equitum Arcadum, classis in Plateypegiis.

I. The Scythian section of Notitia Dignitatum records cuneus equitum Arcadum at Thalamonium ${ }^{1}$. The name of the troop is unique in the long $4^{\text {th }}$ century list of regiments ${ }^{2}$. The $5^{\text {th }}$ and $6^{\text {th }}$ century sources ignore completely such a unit. As the category of unit is well known in the structure of the late Roman army and largely discussed in the modern literature, the issues which needs clarification is the specific term Arcadum, as well as the circumstances of the arrival of the regiment on the Lower Danube frontier.

Although not frequently, the Oriental section of Notitia records both regiments with Imperial title deriving directly from the name of the Emperor Arcadius (395-408) and from the Egyptian province of Arcadia. A high rank regiment, equites Arcades, is mentioned among vexillationes palatinae praesentales ${ }^{3}$. Comites Arcadiaci as a vexillatio palatina was placed

\footnotetext{
${ }^{1}$ NDOr. (O. Seeck, ed.) 39, 18.

${ }^{2}$ Hoffmann 1969, 278; Aricescu 1977, 116; Zahariade 1988, 82-83; 2006, 178. The Scythian section indicates a deployment scheme which, in general maintains the alternance of infantry (milites) with cavalry (cunei equitum) units. A cuneus equitum is placed at Aegyssus, while at Salsovia a unit of milites was billeted. At Thalamonium=Salmorus=Halmyris a cuneus equitum appears in the list, and another infantry regiment (milites) is placed at Gratiana. The latter two regiments are later additions to the Scythian list. It is highly probable that the same deployment scheme must have functioned also during Constantine I and Constantius II period, which would imply the existence of a cuneus equitum at Halmyris, previous to the one recorded by Notitia Dignitatum, but there is no physical evidence whatsoever for the existence of such a cavalry unit. A suggestive example from this view point is the existence of the two cunei equitum Stablesianorum one next to another at Cius and Berroe, in a region where in 368 the military activity was rather intense. After 369, the Imperial program of refortification of the frontier could have modified the alternance scheme cuneus equitum-milites for local tactical reasons. The two nearby cavalry squadrons were preferred in a key strategic position. On the other hand the alteration of the initial Constantinian scheme along the Lower Danube took also place in other sectors (Zahariade 1988, 80-81).

${ }^{3}$ NDOr. 5, 32; Hoffmann 1969,278, 492-493, 499.
} 
under the command (sub dispositione) of magister militum per Thracias ${ }^{4}$. An ala Arcadiana nuper constituta appears under the command of comes rei militaris per Aegyptum ${ }^{5}$. The ala had been created "recently" (nuper), shortly before it was displayed in the list of the regiments under the authority of the Egyptian comes and previous to its final revision and delivery to the primicerius notariorum at Ravenna. The regiment bears the imperial title after Arcadius, the son of Theodosius I and does not have indicated the place of garrison.

Regiments had been successively created during the reign of Theodosius I through the transformation of both field and frontier units ${ }^{6}$. Two units, the palatine and riparian ones, equites Arcades and cuneus equitum Arcadum bear the clear indication of the province of Arcadia part of the diocese of Egypt. The terms Arcades (Arcadians)/Arcadum (of those from Arcadia) shows specifically that they had been established with recruits drawn from the province or rather with troopers from older units stationed in the province of Arcadia.

Arcadia, as a province, was created by Theodosius I sometimes between 386 and 392 through the reorganization, of the two already extant provinces since 341: Augustamnica (the former Aegyptus Herculia=Heptanomia, to which had been added the eastern part of the Nile delta and therefore enlarged); the small province of former Aegyptus Iovia, which in 341 had been diminished and renamed simply Aegyptus. Theodosius I detached most of the territory of Augustamnica, specifically the former Heptanomia into a separate province and renamed it Arcadia in honor of Arcadius, his son who had been proclaimed Augustus in January of 383 at the age of five or six. The territories of the remaining part of Augustamnica together with Aegyptus were reunited into a new province, Aegyptus, as a military district under the command of a dux in $381^{7}$.

Thalamonium, the fort in Scythia where the cuneus equitum Arcadum was biletted is a hapax in the Roman toponymy. The place name is a corruption from the Salmorus which is recorded in Itinerarium Antonini as a Latin variant of the Greek Halmyris ${ }^{8}$. The fort is situated $2.5 \mathrm{~km}$ east from the present day Murighiol commune, Tulcea County, on the southern shore of the Sf. Gheorghe branch of the Danube 9

The history of regiment and particularly the term Arcadum focused the attention of D. Hoffman, A. Aricescu and the author of this article ${ }^{10}$.

D. Hoffmann suggests the setting of this regiment on the basis of the cabaline stock in the Peloponesian Arcadia. He invoked the exceptional quality of the horses from that region backing his assumption on a passage of Sidonius Apollinaris ${ }^{11}$ who mentions a delivery of such good quality horses for the army. That there was a good stock of Arcadian horses is perfectly possible and even probable, but it is hardly acceptable that a horse gathering in Arcadia, a

\footnotetext{
${ }^{4}$ NDOr. 8, 25; Hoffmann 1969, 17-18;243-244; 278-279. As some of the regiments labelled comites hold an ethnical significance (Alani: NDOr. 6, 8=50=7, 163; Armeni: NDOr. 6, 31; Taifali: NDOr. 5, 31) one might think, as D. Hoffmann believes, that comites Arcadiaci could have been also recruited from among externae gentes.

${ }^{5}$ NDOr. 28, 8=21; Hoffman 1969, 23.

${ }^{6}$ Jones 1964, 359-360; Hoffmann 1969, 278.Williams, Friell 1994, 64, 159.

${ }^{7}$ For the successive $4^{\text {th }}$ century reorganizations of Egypt see: Gelzer 1909, 57-71; Bury 1923, 129-130; Jones 1971, 336 and note 50.

${ }^{8}$ It. Ant. 226, 4 (Salmorus); Moisil 1909, 89; Scutum Durae Europi, as the earliest source (ca. 238/240), records it as OYLMYRIA, while the $6^{\text {th }}$ century Greek sources give invariably Halmyris ('Almuríß). De SS Epicteto presb. et Astione monaho martyribus Almiridensibus in Scythia) (ActaSS II Iulii 540-551) uses invariably Almiris, a term borrowed from Greek. On Thalamonium as a corruption: Thalamonium-Thalamorium-Salamorium-Salmorus, with Th (Q) read in Greek manner as S, an equivalent for Halmyris, see also Suceveanu, Zahariade 1987, 87-96 with the bibliography.

${ }^{9}$ Suceveanu, Zahariade, Topoleanu, Poenaru-Bordea 2003, 9.

${ }^{10}$ See note 2 .

${ }^{11}$ Carm. 5, 54 (C. E. Stevens, ed. Oxford 1933).
} 
province which usually did not offer recruits, in the benefit of the Roman army, had such an impact on the naming and officially listing of a military regiment ${ }^{12}$.

The term Arcadum for the Scythian cuneus, which accords in genitive plural with the noun, equitum, is not an imperial title, as it is the case of ala Arcadiana, otherwise the designation would have been cuneus equitum Arcadianorum, as shown by other examples among which one on the very border of the Danube line, in Dacia Ripensis, cuneus equitum Constantinianorum $^{13}$. A. Aricescu thinks that the province of Arcadia provided recruits for the Scythian cuneus equitum Arcadum ${ }^{14}$. In 1984 and later in 2006 I brought new fresh arguments in favour of this assumption. The creation of a new regiment whose name mirrors its origin in the province of Arcadia, as well as its composition with recruits and/or troopers transferred from other units stationed in the province, what promted the very specific term Arcadum, remain thus far the most judicious explanation.

According to a passage in Philostorgios the town of Halmyris was taken by surprise by the barbarians in the winter of 384/5, by the time when the Arian bishop Eumenius lived in exile

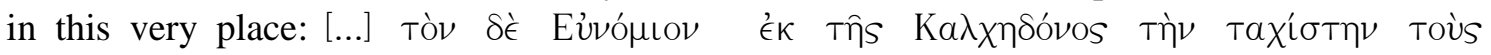

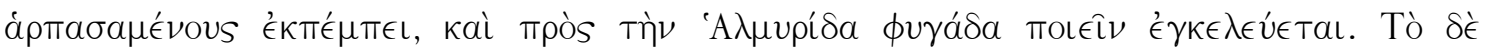

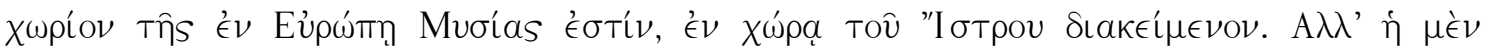

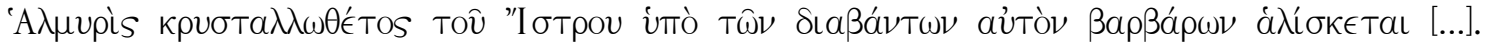

Transl. As for Eunomios, he (i. e. the Emperor) sent people to pick him up immediately from Chalcedon and ordered to be banished at Halmyris. This is a place in Moesia, in Europe, situated nearby Hister River. But Halmyris was taken by the barbarians who crossed the Hister River when it was frozen over [...] $]^{, 15}$.

The inroad, whose authors must have been either some remnant Gothic bands in the Danube delta or the Huns, was certainly a disaster for the fortress. We ignore the name of the auxiliary unit billeted at Thalamonium/Salmorus previous to 384. It must have perished during the sack of the fort, a fact that would entail the erasing of its name from the official list of the Roman army.

The fortress shows clear archaeological evidence of a massive reconstruction by late $4^{\text {th }}$ and early $5^{\text {th }}$ century ${ }^{16}$. The place maintained its strategical importance at the mouth of the Danube which required a new garrison involved in the general rebuilding activity. As the regiment cuneues equitum Arcadum can not be conceived to have been created previous to the establishment of the province of Arcadia, from where its contingents could have originated, the setting of the new garrison at Thalamonium/Salmorus shortly after the 384/385 disaster appears most likely.

The late record of this regiment in the Scythian section of the Notitia Dignitatum (after 384/5) is only explainable through a constant updating of its successive but distinctive segments

\footnotetext{
${ }^{12} \mathrm{cf}$. Them.Or. 24, $305 \mathrm{~d}$.

${ }^{13}$ ND Or. 42, 21.

${ }^{14}$ Aricescu 1977, 116.

${ }^{15}$ Phil. Hist. Eccl. 10. 6 (J. Bidez, ed. Leipzig 1913).

${ }^{16}$ The 1983 and 1985 and 1991and 1997 archaeological and architectonic observations at the North-Eastern gate seem to confirm the late $4^{\text {th }}$ century disaster the fortress went through. The massive late $3^{\text {rd }}$-early $4^{\text {th }}$ century Tetrarchic reconstruction, displays in its first phase a three vaulted gateways monumental portal opening between the towers I and II, as the most important access gate towards the port. The right side of the tower II contained a rectangular room with a door opening outwards which seems to have served as a customs point in a transit area during the first three quarters of the $4^{\text {th }}$ centuries. In its second phase the North-Eastern gate was completely sealed by a massive wall made of cyclopean limestone blocks, set as a curtain wall between tower gate I and curtain tower II shortly after the 384/385 disaster. The customs point which fell outside of the new wall line, together with the traffic and commercial activities through the North-east gate ceased completely. It is also in this period when the Halmyris harbour ceased to function.
} 
which compose this document. It is widely accepted that the editor(s) of the Western and Eastern sections used older lists which had been updated regularly and wrote up a rough sketch of what we know today as Notitia Dignitatum in partibus Orientis and Notitia Dignitatum in partibus Occidentis ${ }^{17}$. Hoffmann accurately defined the updating of the oriental section of the Notitia up until May $394^{18}$. The list of the Scythian section could have been therefore updated with the last modifications in the tactical scheme even after 384/385 when the garrison of the Halmyris fort was presumably taken over by the cuneus equitum Arcadum.

The basic tactical frontier arrangements of Constantine, Constantius II and Valens as illustrated by the Scythian section of the document could have survived, for there is hardly conceivable that all the 22 garrisons on the Danube recorded in the document had perished during the events following the disaster of the Roman army at Hadrinople, in 378, when the Gothic banditry stressed on plundering the rich towns and countryside south of the Haemus mountains. Beside the general strategic consequences, the repair of the serious casualties suffered by the Roman army in the two years continuous combats (377-378), clashes and skirmishes required long term and steady imperative recovery measures under the pressure of the events, not always favorable to the Empire ${ }^{19}$.

According to Zosimus, measures have been taken shortly after the Hadrinople disaster to restore the Imperial authority in the ravaged Balkan provinces. R. T. Ridley's chronology of Zosimus dates the first significant Theodosian intervention in the military field in $379-380^{20}$, which is quite early but a reasonable date for the restoration of the Imperial authority way before the conclusion of the peace treaty of 3 October 382 . Zosimus alludes to a period shortly after the Roman army's disaster which entailed the allowance of some Germanic groups to be enrolled into the feable, at that time, Roman army. Although the chronology of Zosimus is often erratic given the the author's penchant for contraction of the events, the information in itself remain highly reliable ${ }^{21}$.

For these early measures there is one main passage in Zosimus under discussion:

IV 30. 1: "[...] When the emperor Theodosius saw the army much depleted, he allowed any of the barbarians beyond the Danube who wished to do so to come to him, promising to enrol the deserters in the legions. Many accepted this agreement and joined the Roman soldiers, with the idea that as soon as their numbers increased they could easily attack ande gain complete control. 2. The Emperor, seeing that the deserters were already more numerous than the other soldiers and realising that they could not be restrained if they decided to mutiny, thought it better mix some of them with the soldiers in Egypt and to replace them with some of the soldiers serving in the legions there [...]". 3. So one detachment came and the other went as the emperor ordered, but while the Egyptians marched quietly through the cities and bought what they needed at a fair price, the barbarians proceeded in disarray and behaved selfishly in the markets. 4. When the two detachments met at Philadelphia in Lydia, the Egyptians, who were much fewer than the barbarians, observed discipline, while the barbarians began to be arrogant. And when one of the traders in the market-place asked payment for the goods he had sold, the barbarian used his sword on him. He shouted and another man who tried to help was struck also. The Egyptians took pity and urged the barbarians in reasonable terms to refrain from such offensive behaviour, saying that this was not the action of men who wished to live

\footnotetext{
${ }^{17}$ Jones, 1964, 347-358; Clemente 1968, 25-63; Hoffmann 1969, 49-53.

${ }^{18}$ Hoffmann $1969,52$.

${ }^{19}$ Williams, Friell 1994, 2-9; Whitby 2002, 44-45.

${ }^{20}$ Ridley 1982, 83-84.

${ }^{21}$ Petre1965, 263-272; Goffart 1971, 412-441; Cameron1969, 106-110; Scavone1969, 57-67; Ridley 1972, 277302.
} 
under Roman law. 5. Thereupon the barbarians drew their swords against them also until the Egyptians lost their temper and attacked them. More than two hundred were killed, others wounded, and the rest forced to flee to the sewers, where they died. This is what the Egyptians did to the barbarians in Philadelphia to convince them that unless they were more restrained, they would not lack enemies. The Egyptians then continued on their way, and the barbarians marched towards Egypt, as they were required, under the command of the Persian Hormisdas.

31. 1. When the Egyptians reached Macedonia and joined the legions there, there was no discipline among the soldiers; no distinction was made between Roman and barbarian, with everyone living together indiscriminately, and no record kept of those enrolled in the army. And the deserters, even those already enlisted in the legions, were allowed to return home and send others in their place, and then to serve again under the Romans whenever they wanted. 2. When the barbarians understood, on the information of the deserters who had unrestricted access to the Romans, the confusion prevalent in the legions, they thought that now, while chaos was widespread was their opportunity to attack. 3. They crossed the river easily and reached Macedonia without opposition because the deserters allowed them to cross wherever they wanted. Learning that the emperor was advancing against them with his whole army and seeing a great fire burning in the dead of night (which they concluded was near the emperor and his army, as was confirmed by the deserters who came over to them), they used the light to guide them to the emperor's tent. 4. When the deserters joined them, only the Romans and such of the Egyptians as were present opposed them. Although vastly outnumbered and unable to hold out, they nevertheless gave the emperor a chance to escape; they themselves all fell fighting bravely and not before they had killed a vast number of barbarians. 5. Had the barbarians followed up their advantage and pursued the fleeing emperor and his retinue they would have overpowered them completely without a blow, but satisfied with their victory, they took over the unprotected provinces of Macedonia and Thessaly, and let the cities go without doing them any harm, in the hope of gaining a reasonable tribute from them [...]" (transl. T Ridley 1982).

Although sketchy and apparently contradictive, the dramatic story of the transfer of the Egyptian effectives to the Lower Danube sounds entirely veracious. Changes of troops between Egypt and Danube lands occurred since $2^{\text {nd }}$ century although not as a continuous and preferential process $^{22}$. The military circumstances described by Zosimus were exceptional and the diocese of Egypt, which might have had intact military forces, was at that moment the best fit to sustain such a transfer.

The local disaster at Halmyris in the winter of 384/385 and any urgent transfer of a regiment destined to replace the lost garrison would have been preferable and could have happened after that date.

Any attempt to identify some other transfers from the Egyptian field army regiments to Thrace during the reign of Theodosius I bear a high degree of uncertainty. The Thracian list of the field army and the account of Ammianus displays indeed traces of a transfer of legiones comitatenses of Egyptian origin: Prima Maximiana Thebaeorum, Tertia Diocletiana Thebaeorum and possibly Iulia Alexandria but they had been moved already by mid $4^{\text {th }}$ century $^{23}$. The army lists for the Egyptian provinces and Thracian diocese, as well as those in the city capital, Constantinople show weak sign of such transfers as yet, which makes the identification of such regiments highly uncertain and less succesful. However, the fact is far

\footnotetext{
${ }^{22}$ Transfer from Egypt to the Danubian provinces: e. g. cohors I Hispanorum veterana quingenaria (Fink 1958, 102-116; Syme 1959, 26-33; Vulpe 1960, 337-357; Petolescu 2002, 109-110); ala II Hispanorum (P. Cairo 78).

${ }^{23}$ The Egyptian sections in Notitia: NDOr. 28, 14-46 (comes limitis Aegypti); 31, 23-67 (dux Thebaidos); Hoffmann 1969, 238; 337; 353; 508-509; 511-513; Amm. Marc. XIV 11. 15 (Thebaeas legiones in vicinis oppidis <i.e. Hadrianopolis> hiemantes).
} 
from affecting the credibility of the Zosimus' account ${ }^{24}$ and the reassigning of troops from Egypt to the Lower Danube and viceversa must be considered as as an important detail. Nevertheless, the only regiment to have been transferred from Egypt, highly identifiable on the Scythian duke's list seems cuneus equitum Arcadum.

The insertion of the name of the regiment in the Scythian list could have been done sometime between 386/392 and before ca. 394/395 the date of the delivery of the Pars Orientis towards primicerius notariorum at Ravenna. The final editor of the Scythian section placed therefore the regiment in the very place where it took position, i.e. at Thalamonium $=$ Salmorus $=$ Halmyris. It must have replaced a previous regiment presumably completely or in its biggest part destroyed during the events of 384/385. The replaced unit must have been also of a cuneus equitum type according to the initial Constantinian scheme.

On the other hand, once garrisoned at Thalamonium/Halmyris, cuneus equitum Arcadum was massively involved in the Theodosian considerable reconstruction works archaeologically identified in the fort with the level of occupation VIII ${ }^{25}$.

II. The Scythian section of ND records some naval units as follows:

35. Praefectus ripae legionis primae Ioviae cohortis [...] et secundae Herculiae musculorum Scythicorum et classis Inplateypegiis.

A. Aricescu suggested cohors musculorum Scythicorum under the competence of both legions, while for classis Inplateypegiis the author proposed a particular naval unit of classis formed of flat bottom boats under the command of a praefectus. He rejected Remondon's and Pippidi's suggestions of a place name born as a result of the existence of a base sheltering a particular type of ships, $\pi \lambda \alpha \tau u \pi n ́ \gamma\left\llcorner\alpha^{26}\right.$.

In 1988 I set forth the likelihood that the passage in NDOr could be read classis in [loco] Plateypegiis. The noun locus is to be interpreted possibly as a base (reliquatio) of the fleet

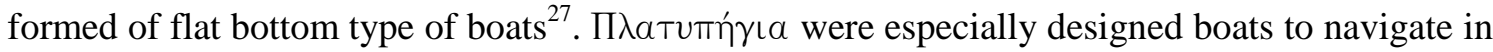
the deltaic environment of the Nile delta. The large scale utilization of such boats in this region prompted their record in a significant number of Egyptian papyri ${ }^{28}$.

It is difficult to ascertain the circumstances in which these boats commenced to be used in the Danube delta. The sending of such boats from Egypt overseas to Scythia Minor is unlikely, as long as the two deltaic areas were alike and the solutions of navigation could have been similar. The operation would have been very risky for such a long way. Boats of that type could have existed also in the Danube delta, possibly long time before their record in Notitia Dignitatum, although we ignore how they were called in the local milieu ${ }^{29}$. The main issue is

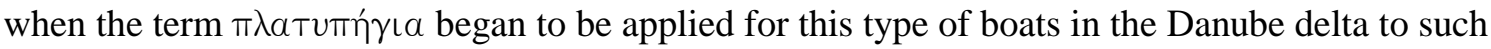
a scale that it became generalized and imposed a specific designation of an entire naval unit and even, presumably, a place name.

Remondon thinks that the term the soldiers of the Danubian legions involved in the military operations in Egypt during Diocletian's time made acquaintance with was introduced in Scythia after they returned to the Danube, by the end of the $3^{\text {rd }}$ century ${ }^{30}$. It could be so, but

\footnotetext{
${ }^{24}$ Zos. 4, 30, 3-5; 31, 1-5.

${ }^{25}$ Suceveanu, Zahariade, Topoleanu, Poenaru-Bordea 2003, 36.

${ }^{26}$ Aricescu 1977, 120-121. On platypegia see: Remondon, 1954, 199-210; Pippidi 1965. 330-332; Bounegru, Zahariade 1996, 69.

${ }^{27}$ Bounegru, Zahariade 1996, 27.

${ }^{28}$ Remondon 1954, 199-210, especially 205-207.

${ }^{29}$ Pippidi 1965, 332.

${ }^{30}$ Remondon 1954, 209-210.
} 
many of the Danubian legionary detachments never returned to their homes after they were split from their mother units and assigned for specific missions outside the province.

In mid $4^{\text {th }}$ century, Themistios adduces some fresh lights on the subject ${ }^{31}$. The rhetor insists on the fact that the deltaic regions were "poorely defended against the barbarians, for the river which crosses it over does not have a continuous course and it is mixed with firm land and forms a marshy and unnavigable gulf which deepens much, where the to walk is impossible. This region had been a kind of a hide out before, wherefrom their attacks were fomented; daring to overtly invade by bands because the peace, which was only for the sake of appearance, stopped them, they did thefts and unlawful actions in single row oared boats; they were on the watch in their boats, hidden in the aits and rushed unexpectedly at the local people in the proximity. Then, until the garrisons, set far from one another, to take notice they raided at their will and after that sunk into the river. From that moment on, nobody could ever chase them, for either the boats or foot could not break through the marshes. It was something unbearable to see pillage in sight of everybody, without the accomplisher can be punished".

The passage is an excellent picture of the then situation in the Danube delta, and in the neighboring areas. Otherwise accurate and detailed on the description of the reconstruction and repair of the frontier defence structures, which augments its credibility, Themistios refers mainly to the right bank of the river but also contains elements which bring up the maritime component of the program. The rhetor speaks about: $\lambda \iota \mu \epsilon ́ v \in S$ Tñs

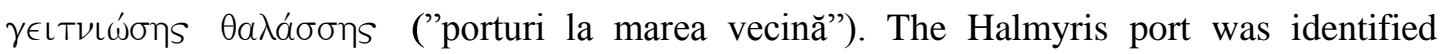
through aerial photography and it could have been well included in the list ${ }^{32}$. Even if not complete and envisaging only some critical segments of the frontier, the reconstruction activity would have implied measures taken to increase the efficiency of the naval component to patrol, prevent, and thwart future inroads.

The period between 369 and 372, when the entire Imperial rebuilding program was carried on, could be considered as a time for the implementation of the new term $\pi \lambda a \tau U \pi \eta ́ \gamma l \alpha$ at the Lower Danube, but the date is not undebatable. Another episode which could have triggered the commencement of the circulation of the term is that of the transfer of some Egyptian units to the Lower Danube in or shortly after 379-380.

It is true that Zosimos' text does not indicate what specific units had been transferred. Among infantry or cavalry regiments which left Egypt some soldiers involved in naval activity could have been presumably assigned for specific activities in the Danube delta, as part of the reconstruction program of the Danubian naval forces. On the occasion of the transfer of the cuneus equitum Arcadum the implementation of the term platypegia could have come into being in the Danube delta where, very likely, such type of boats have been already functioning, although had presumably been labelled differently from the Egyptian term.

\section{BIBLIOGRAPHY}

Aricescu 1977 - A. Aricescu, Armata în Dobrogea romană, Bucureşti.

Bury 1923 - J. Bury, The Verona list, JRS 13, 127-151.

Cameron 1969 - A. Cameron, The Date of Zosimus' New History, Philologus 113, 106-110.

Clemente 1968 - G. Clemente, La Notitia Dignitatum, vol. I-II Cagliari.

Fink 1958 - R. O. Fink, Hunt's pridianum: British Museum Papyrus 2851, JRS 48, 102-116.

${ }^{31}$ Them. Or. X 136 (R. J. Penella ed. U. C. Press, 2004).

${ }^{32}$ Bounegru, Zahariade 1996, 87-88. 
Gelzer 1909 - M. Gelzer, Studien zur byzantinischen Verwaltung Ägyptens, Leipzig.

Goffart 1971 - W. Goffart, Zosimus as a witness to his own time, American Historical Review 76, 2, 412-441.

Hoffmann 1969 - D. Hoffmann, Das Spätromische Bewegungsheer und die Notitia Dignitatum, Teil III Epigraphische Studien 7/1, 2 Dusseldorf.

Jones 1964 - A. H. M. Jones, The Later Roman Empire. 284-602. vol. I-III Oxford.

Jones 1971 - A. H. M. Jones, The Cities of the Eastern Roman Empire, Oxford.

Penella 2004 - R. J. Penella, The Private Orations of Themistius, The Transformation of the Classical Heritage, XXIX UC Press, Berkley, New York, London.

Petolescu 2002 - C. C. Petolescu, Auxilia Daciae, Bucureşti.

Petre 1965 - Z. Petre, La pensée historique de Zosimos, StCl 7, 263-272.

Pippidi 1965 - D. M. Pippidi, O aşezare uitată din Dobrogea romană, $\mathrm{StCl}$ 7, 330-333.

Remondon 1954 - R. Remondon, Un nouveau document concernant Probus, Revue Philologique 28, 199-210.

Ridley 1982 - R. T. Ridley, Zosimos' New History. A Translation with Commentary, Sydney.

Ridley 1972 - Ridley, Zosimus the Historian, Byzantinische Zeitschrift 65, 377-302.

Scavone 1969 - D. Scavone, Zosimos and his Historical Models, Greek Roman and Byzantine Studies 11, 57-67.

Suceveanu, Zahariade 1987 - Al. Suceveanu, M. Zahariade, Du nom antique de la cité romaine tardive d'Independența (dep. Tulcea), Dacia N.S. 31, 1-2, 87-96.

Suceveanu, Zahariade, Topoleanu, Poenaru Bordea 2003 - Al. Suceveanu, M. Zahariade, F. Topoleanu, Gh. Poenaru Bordea, Halmyris I. Monografie arheologică, Cluj Napoca.

Syme 1959 - R. Syme, The Lower Danube under Trajan, JRS 49, 26-33.

Vulpe 1960 - R. Vulpe, Muntenia şi Moldova de jos în timpul lui Traian în lumina unei noi lecturi a papirului Hunt, $\mathrm{StCl} 2,337-357$.

Whitby 2002 - M. Whitby, Rome at War. A. D. 293-696, Oxford.

Williams, Friell 2005 - St. Williams, G. Friell, Theodosius I. The Empire at Bay, London.

Zahariade 1988 - M. Zahariade, Moesia Secunda, Scythia şi Notitia Dignitatum, Bucureşti.

Zahariade 2006 - M. Zahariade, Scythia Minor. A History of a Later Roman Province (284-681), Amsterdam. 